\title{
Ionic Liquids: From Synthesis to Applications in Solar Cells
}

\author{
Zhaofu Fei, Valentin M. Manzanares, and Paul J. Dyson*
}

\begin{abstract}
Ionic liquids continue to find applications in an ever-increasing range of technologies. Here we describe some of the key routes used to prepare ionic liquids and then relate their properties to their applications. In particular, ionic liquids have been used to facilitate crystal growth and, for this reason, are emerging as useful solvents/additives in the preparation of perovskite films. The role of ionic liquids in these films and how they lead to perovskite solar cells with high efficiencies and stabilities is described.
\end{abstract}

Keywords: Ionic liquids · Perovskite films · Solar cells

\section{Introduction}

Solvents play a critical role in virtually all aspects of chemistry, and consequently also in many other areas of science and technology. While nature depends largely on water, modern chemistry is based extensively on the use of organic solvents. Recent trends have been to apply natural solvents, supercritical fluids, switchable solvents and ionic liquids (ILs) as environmentally more acceptable alternatives to organic solvents.

ILs comprise a highly diverse and versatile class of solvents, ${ }^{[1,2]}$ that can be engineered for specific applications, greatly expanding on their role simply as a solvent. ${ }^{[3,4]}$ They have already found numerous industrial applications. [5] ILs have been used in process intensification, ${ }^{[6]}$ liquid lenses, ${ }^{[7]}$ and even in electrospray thruster technology. ${ }^{[8]}$ Key properties of ILs include their very low vapour pressure, ${ }^{[9]}$ high thermal stability, ${ }^{[10,11]}$ and electrochemical stability over a wide range of conditions. ${ }^{[12]}$ However, one of the most attractive features of ILs is the possibility to design them with specific properties for specific applications. ${ }^{[13,14]}$

\section{Synthesis of Ionic Liquids}

Any salt with a melting point of $<100{ }^{\circ} \mathrm{C}$ may be considered as an IL, according to the widely accepted definition, ${ }^{[15]}$ implying that the field spans many different domains, which is reflected in the sheer number of possible structures (Fig. 1). Regardless of the skeleton employed, a large number of aliphatic, polar or (hetero)aromatic substituents can be incorporated in ILs to tailor their physical and chemical properties.

The imidazolium ring is a particularly versatile IL scaffold with a variety of methods available to derivatize both the nitrogen and carbon rings atoms (Scheme 1).[16] Quaternization of imidazoles proceeds readily with most alkyl halides and, if the reaction is sluggish under microwave, dielectric heating or sonication accelerates the reaction.[17,18,19] Quaternization is usually followed by anion exchange. Symmetrical $\mathrm{N}, \mathrm{N}$-derivatized imidazolium salts are readily obtained from imidazole, using strong bases to deprotonate the nitrogen atom $^{[20,21]}$ or by displacing a trialkylsilyl protecting group (Scheme 1), ${ }^{[22]}$ the latter route being very versatile.

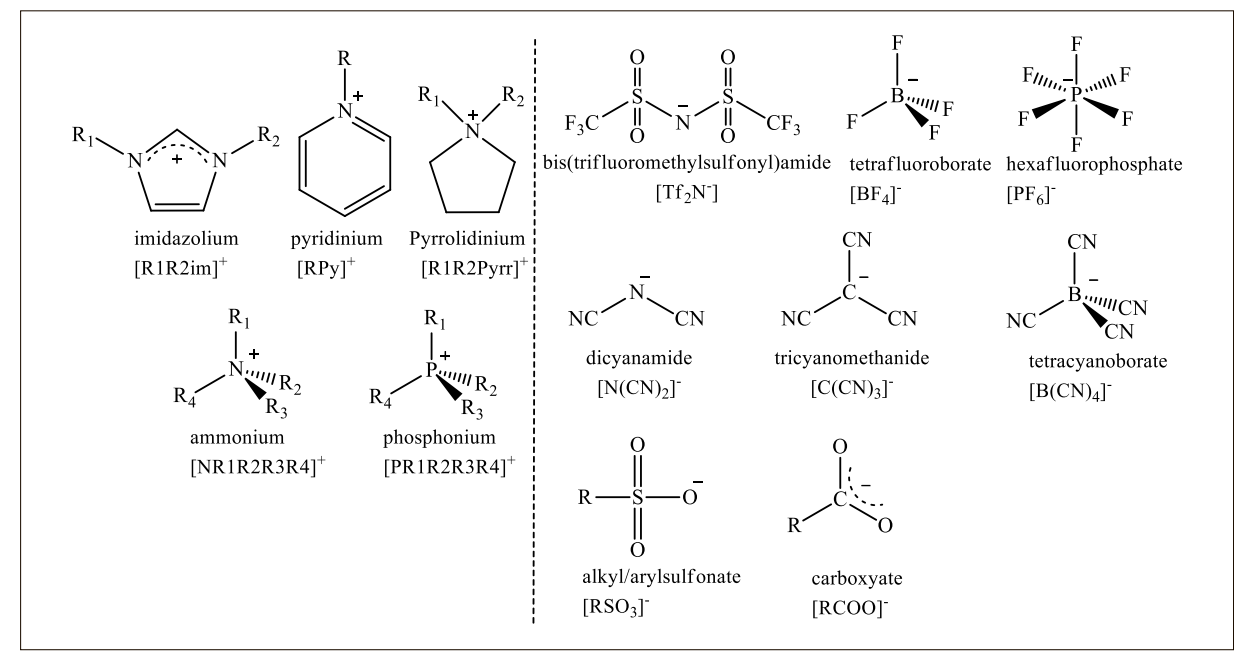

Fig. 1. Examples of common cationic (left) and anionic (right) IL constituents. Many variations and themes on these basic structural types exist $\left(R, R_{1}-R_{4}=\right.$ alkyl).

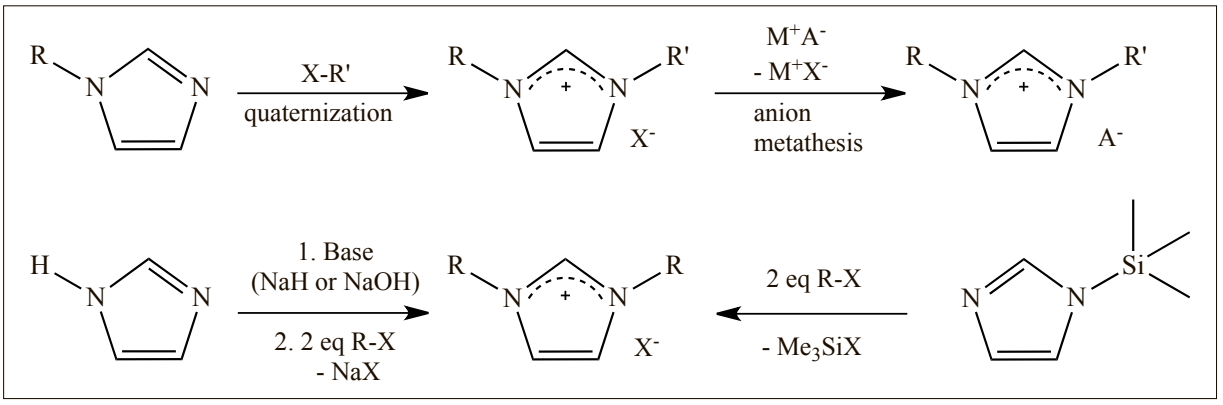

Scheme 1. Widely encountered two-step route used to prepare imidazolium-based ILs from imidazoles (top). Main synthetic routes used to prepare symmetrical $\mathrm{N}, \mathrm{N}$-functionalized imidazolium salts (bottom) $\left(R, R^{\prime}=\right.$ alkyl). 
Although alkyl halides and pseudohalides are the most commonly encountered alkylating agents, the resulting halide anions can sometimes be difficult to eliminate in subsequent metathesis reactions. ${ }^{[23,24]}$ There are various alkylating agents that avoid halides, including trialkyloxoniums, ${ }^{[25]}$ dimethyl carbonate, ${ }^{[26]}$ or alkyl orthoformates together with the conjugate acid of the counteranion. ${ }^{[27]}$ The Mitsunobu reaction of an alcohol and a protonated imidazole or pyridine has also been employed to generate halide-free ILs. ${ }^{[28]}$

An attractive synthetic route to ILs that makes use of naturally occurring reagents such as amino acids and sugar derivatives provides access to a large number of chiral, Zwitterionic ILs (Scheme 2). ${ }^{[29]}$ The method is also compatible with non-chiral alkylamines affording dialkylimidazolium acetates.

A wide variety of N-heterocyclic systems can be used as building-blocks for the synthesis of ILs, with the diversity of certain heterocyclic scaffolds and their ubiquity from natural resources being advantageous. Interestingly, key toxins produced by two warring ants species, i.e. solenopsins and formic acid, react to afford a piperidinium-based protic IL (Scheme 3). [30]

Azolium-based ILs share some of the broader characteristics of imidazolium-based ILs and, moreover, 1,2,3-triazoles can be prepared with a large variety of functional groups from the corresponding alkyne and azides using the copper-catalyzed azide-alkyne [2+3] cycloaddition reaction (Scheme 4).[31] Of these, bicylic triazolium salts are particularly stable and act as electrolytes in organic solar cells. ${ }^{[32]}$

Many ILs are composed of non-heterocyclic cations such as ammonium and phosphonium cations (Fig. 2). Amines are prevalent in natural products and provide a rich source of ILs. For example, cholinium salts display low toxicities and are biodegradable, [33-35] and betainium-based ILs can be easily prepared from the betaine zwitterion. ${ }^{[36,37]}$ Tetraalkylphosphonium salts tend to be more stable than their ammonium counterparts under thermal conditions, ${ }^{[38]}$ and a promising application of phosphonium-based ILs is as lubricants. ${ }^{[39-41]}$

An alternative reaction to alkylation to generate ILs involves the protonation with a Brønsted acid to afford protic ILs (Scheme 5). The resulting salts generally display high conductivities and form strong H-bonds. ${ }^{[42,43]}$ An important parameter for the formation of protic ILs is the $\mathrm{pK}_{\mathrm{a}}$ of the acid, as neutralization must be complete otherwise mixtures are formed. Interestingly, proton transfer from the cation to the anion allows protic ILs to be distilled. ${ }^{44-46]}$

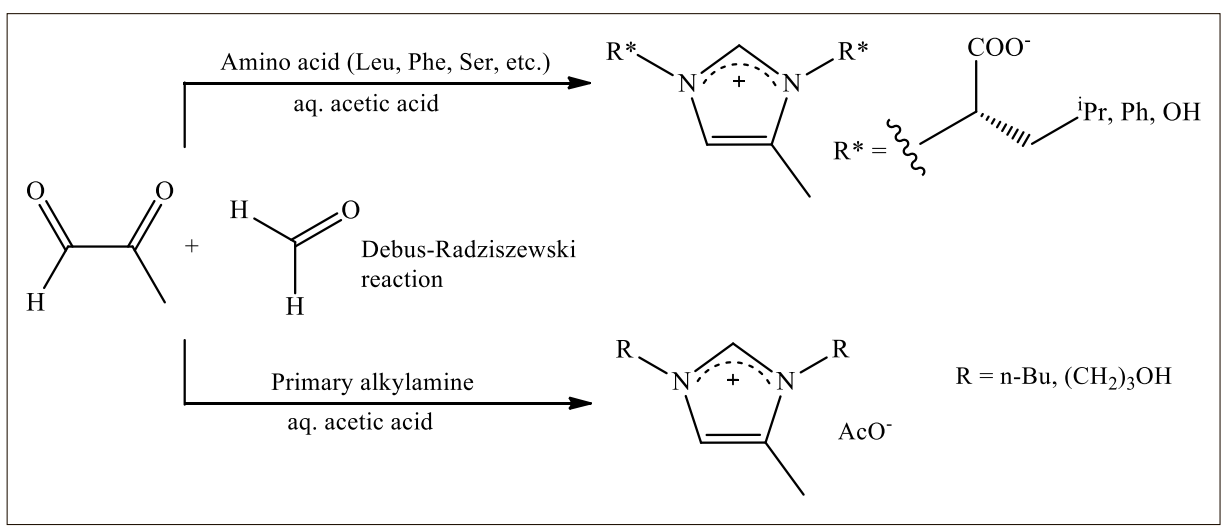

Scheme 2. Synthesis of symmetrically functionalized ILs via the Debus-Radziszewski reaction.

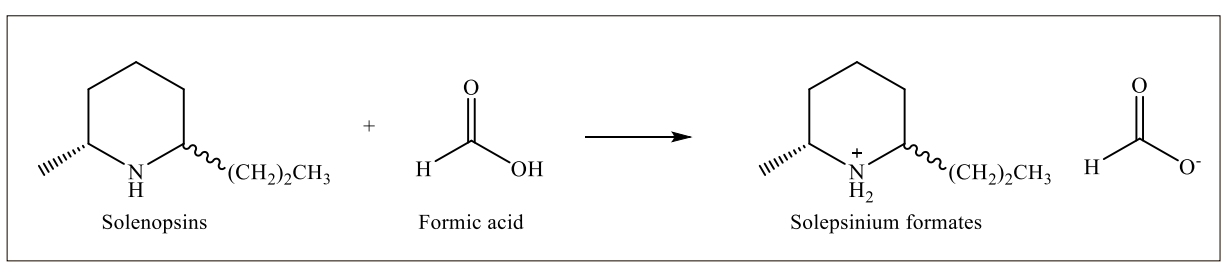

Scheme 3. Formation of an IL derived from ant toxins.

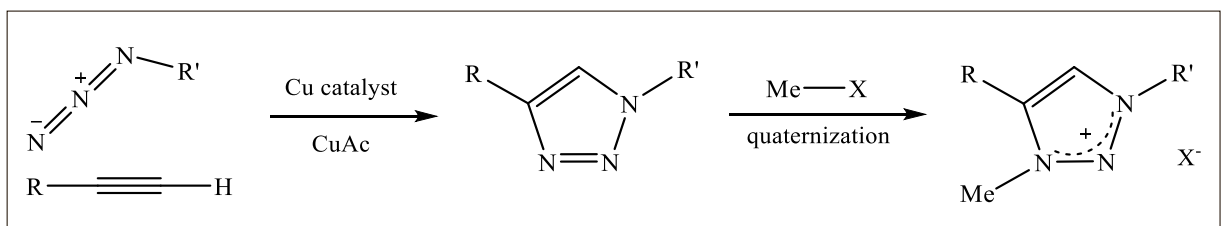

Scheme 4. Synthesis of 1,2,3-triazolium ILs via click chemistry allowing a wide range of different groups to be incorporated into the 1,2,3-triazolium ring $\left(R, R^{\prime}=\right.$ alkyl).
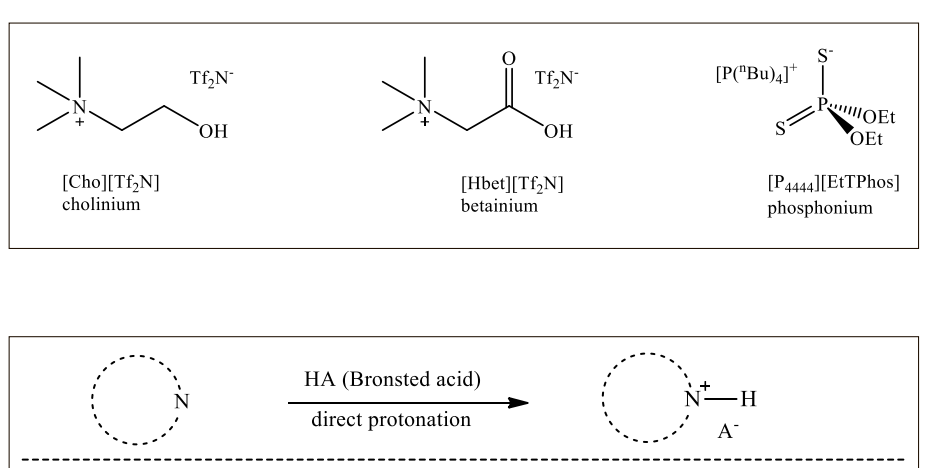<smiles>CC[NH+]([O-])[O-]</smiles><smiles>C1CN=C2NCCCN2C1</smiles><smiles>CN(C)C(=[NH+])N=[NH+]C(C)(C)C</smiles>

$\left[\mathrm{EtNH}_{3}\right]\left[\mathrm{NO}_{3}\right]$ (EAN)

$[\mathrm{TMG}]\left[\mathrm{CF}_{3} \mathrm{COO}\right]$
Scheme 5. A general route for the synthesis of protic ILs and representative examples of protic ILs.
Fig. 2. Representative examples of ammonium- and phosphonium-based ILs.

\section{Reactions in Ionic Liquids}

ILs have been extensively used as solvents in catalysis, although it is often difficult to predict how an IL will affect a reaction, as they can interact with the substrates, products and catalyst and even influence transition state intermediates. ${ }^{[47]}$ Consequently, ILs have been classified using Kamlet-Taft solvent parameters, ${ }^{[48-51]}$ which attempt to separate the polarizability $\left(\pi^{*}\right)$ and H-bonding behaviour $(\alpha, \beta)$ 
of solvents.[52] Although ILs are usually highly conductive, their polarity is similar to simple alcohols. ${ }^{[53]}$ Hydrogen bonding strongly contributes to IL-solute interactions, especially for the imidazolium salts which have acidic ring protons. ${ }^{[54]}$ It is generally accepted that the $\mathrm{H}$-bond acidity $(\alpha)$ in most ILs is determined by the cation whereas the $\beta$ parameter is largely dependent on the nature of the anion. ${ }^{[50]} \mathrm{A}$ number of additional interactions including charge screening or charged interactions exist and, hence, ILs display a high level of structural organization at the nanoscale. ${ }^{[55,56]}$ As a consequence of these non-covalent interactions, ILs tend to have higher viscosities than molecular solvents, which can potentially lead to mass transfer problems. For example, in the Diels-Alder cycloaddition of cyclopentadiene with acrylates, reaction rates in tetrafluoroborate-based ILs are slower than those determined in dichloromethane under similar conditions, attributed to the high viscosity of the ILs. ${ }^{[57]}$

One of the earliest applications of ILs in catalysis was in the Friedel-Crafts alkylation of aromatic cycles with alkyl chlorides and alkenes in chloroaluminate ILs (Scheme 6). ${ }^{[58]}$ From a comparison of several chlorometallates, i.e. ILs derived from $\mathrm{AlCl}_{3}, \mathrm{ZnCl}_{2}, \mathrm{CuCl}_{2}$ or $\mathrm{FeCl}_{3}$, high yields and selectivities were achieved in all cases, with the chloroaluminate-based ILs giving the highest yields and selectivities. ${ }^{[59]}$ The high sensitivity of chloroaluminate-based ILs to moisture makes recycling and reuse problematic, [60] nonetheless, chloroaluminate-based ILs continue to find niche applications in synthesis, such as in the preparation of $\beta$-chlorovinylketones from acetylene.[61]

The Diels-Alder cyclization displays a strong endo/exo dependence on the reaction solvent (the ratio has even been used as the basis of a polarity scale). ${ }^{[62]}$ Protic ILs are excellent solvents for the Diels-Alder reaction because of their $\mathrm{H}$-bonding capabilities; protonated imidazolium-based ILs tend to favour the formation of endo products in the reactions of cyclopentadiene and acrylates, ${ }^{[63]}$ especially when combined with weakly coordinating anions such as $\mathrm{Tf}_{2} \mathrm{~N}^{-}{ }^{[64]}$ It has also been shown that both high pressures ${ }^{[65]}$ and catalytic amount of a Lewis acid increase both the yield and selectivity of the reaction. [66]

ILs generally dissolve metal complexes, especially ionic complexes and, consequently, can be used in biphasic catalysis. If the complex is not naturally charged then use of ligands bearing ancillary charges, e.g. sulfonated phosphines such as TPPMS or TPPTS, employed in rhodium-catalyzed hydroformylation reactions, ${ }^{[67]}$ or imidazolium-tagged ligands (see Fig. 3) can enhance a variety of transition metal-catalysed transformations. ${ }^{[68,69]}$
ILs are also frequently used to immobilize and stabilize transition metal nanoparticle (NP) catalysts and an industrial process employing an IL-stabilized Pt NPs has been developed. ${ }^{[70]}$ Indeed, a large variety of NPs have been synthesized directly in ILs or transferred into ILs and used to catalyze various reactions. ${ }^{[71,72]}$ The synthesis of stable NPs solvated in ILs has been achieved via both bottom-up and top-down processes, i.e. the reduction of metal salts and aggregation of small metal clusters or from sputtering of bulk metal foils. ${ }^{[73]}$ In addition, NPs prepared in water can be transferred into IL phases by facile manipulation of the surface properties of the particles.[74,75]

Imidazolium cations have been extensively used as ionic tags to facilitate the recovery and reuse of reagents and catalysts. ${ }^{[76]}$ Notably, imidazolium salts linked to TEMPO radicals could be used as recyclable catalysts for the oxidation of alcohols, ${ }^{[77]}$ and have also found applications in dye-sensitized solar cells. ${ }^{[78]}$ Stoichiometric reagents can be immobilized in an ionic phase in a similar manner and examples of recoverable reagents that can be regenerated and reused include imidazolium-supported hypervalent iodine, ${ }^{[79,80]}$ and sulfoxides, ${ }^{[81]}$ (Fig. 4). ILsupported sulfonyl azides are efficient alternatives for diazo transfer reactions. ${ }^{[82]}$

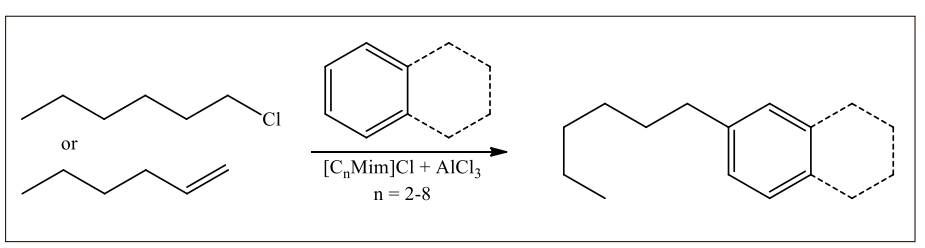

Scheme 6. Prototypical FriedelCrafts alkylation catalyzed by chloroaluminate-based ILs.

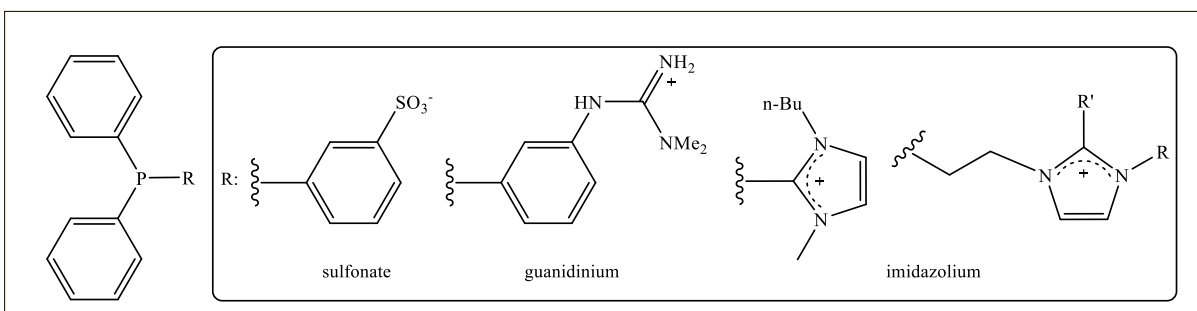

Fig. 3. Examples of phosphine ligands bearing charged groups that, when coordinated to a metal complex (catalyst), anchor the complex in an IL phase to prevent catalyst leaching into an organic (extraction) phase.

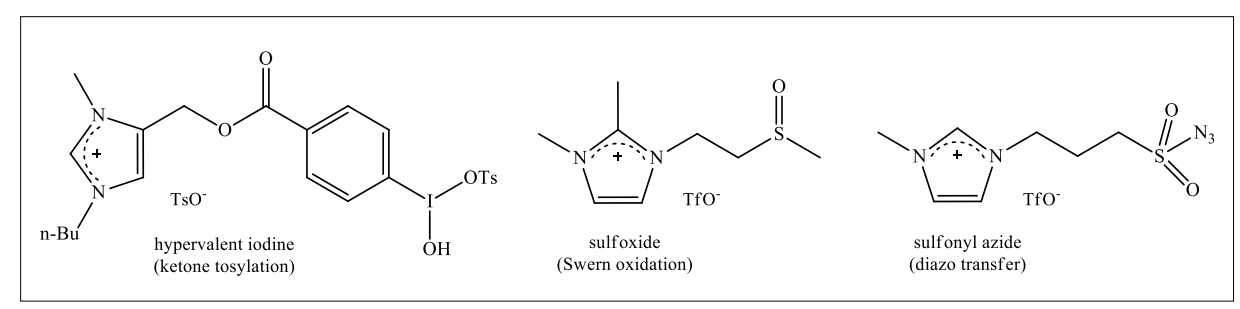

Fig. 4. Representative examples of IL-supported reagents and their applications. 
coordination chemistry and react to form highly interesting MOFs with both main group ${ }^{[95,97]}$ and transition metal ions. ${ }^{[98,99]}$

ILs have been used as solvents in the synthesis of MOFs, ${ }^{[100,101]}$ and are often included in the final structure. ILs with coordinating anions can also form MOFs via coordination to the metal ions, ${ }^{[102]} \mathrm{MOF}$ with large pores are also able to host ILs forming co-called IL@MOF structures. Depending on the size of the pores of the MOFs, the phase behaviour can change once the IL is encapsulated inside the pores. For example, [Emim] $\left[\mathrm{Tf}_{2} \mathrm{~N}\right]$ inside ZIF-8 does not show a phase transition between solid and liquid phases because insufficient ions are present in the pores, which prevents the formation of an ordered crystal structure. As a result of the disorder of ILs inside MOFs the conductivity of ILs remain high even at low temperatures. ${ }^{[103,104]}$

IL@MOF act as absorbents for small molecules such as $\mathrm{CO}_{2},{ }^{[105,106]}$ allowing their use in gas separations. ${ }^{[107]}$ They have also been shown to catalyze the cycloaddition of $\mathrm{CO}_{2}$ to epoxides to form carbonates. ${ }^{[108]}$ ILs have been extensively explored as both solvent and catalyst for this reaction, which is atom-economic, scalable and industrially important. ${ }^{[109]}$ The tunable physicochemical properties of ILs combined with a large number of possible MOF structures opens opportunities for the rational design of materials for gas separations. As an example, employing an amine-functionalized IL, which is known to absorb high levels of $\mathrm{CO}_{2},[110]$ provides an IL@MOF that can efficiently separate $\mathrm{CO}_{2}$ from $\mathrm{CO}_{2} / \mathrm{N}_{2}$ mixtures. [111]

As mentioned above, ILs have been used as solvents for the preparation of zeolites and MOFs, they even aid protein crystallization, and are increasingly being used in crystal engineering. Crystallization strategies using ILs differ significantly from those using conventional organic solvents and many new approaches have been developed. ILs do not simply replace organic solvents in crystallization processes, they also act as a template, and fundamental investigations into the nature of the interactions between the IL ions and the solutes are key to understanding their role. Moreover, due to the low volatility of ILs under high vacuum they can be applied in non-classical solvent-based techniques such as vacuum deposition. ${ }^{[112,113]}$

Since ILs frequently melt at higher temperatures than organic solvents they have been employed in cooling crystallization for the purification of pharmaceuticals. ${ }^{[114]}$ Many pharmaceuticals are poorly soluble in common organic solvents and are therefore not suited to purification from them. ILs such as [Emim] $\left[\mathrm{Tf}_{2} \mathrm{~N}\right]$ are stable at $c a .>300{ }^{\circ} \mathrm{C}$ and are polar, allowing pharmaceuticals to be dissolved in them at

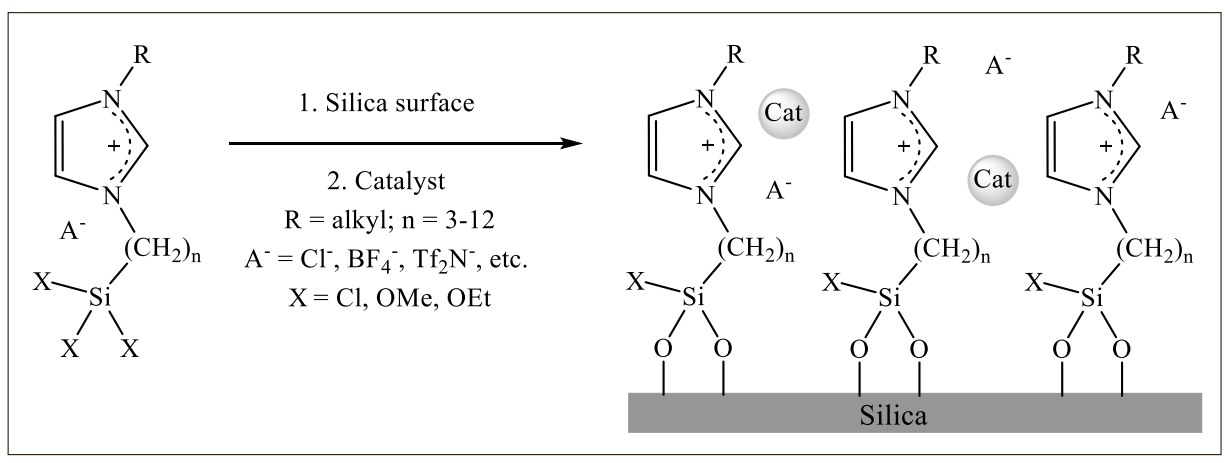

Scheme 7. Modification of a silica surface with a silane-functionalized IL affording a monolayer coating followed by immobilization of an ionic catalyst within the IL monolayer.

elevated temperatures. Subsequent cooling leads to crystallization of the pharmaceuticals. ${ }^{[115]}$ ILs are particularly useful for the solubilization of poorly soluble drugs. ${ }^{[116]}$

ILs have been used as electrolytes in dye-sensitized solar cells (DSSCs) for many years, ${ }^{[117]}$ and recently they have started to gain attention in the crystallization of perovskite layers used in perovskite solar cells (PSCs). Simple, low viscosity ILs tend to be used in DSSCs although functionalized ILs exhibit promising properties, ${ }^{[118-120]}$ although mixing them with molecular solvents that reduce the viscosity can be advantageous. ${ }^{[121,122]}$ Nevertheless, quasi-solid state electrolytes employing ILs have been investigated as they can improve the stability of the device, [123-125]

The role of ILs in the fabrication of perovskite films remains poorly understood, although it would appear that many different attributes of ILs could play pivotal roles. Despite the lower stability of the perovskite solar cells than DSSCs, ${ }^{[126,127]}$ and their potential toxicity as they employ lead, ${ }^{[128]}$ rapid progress has been made and efficiencies exceed $22 \%,{ }^{[129]}$ and higher efficiencies can be expected.[130] The structure of the light-absorbing perovskite film, comprising methylammonium lead iodide often with dopants, is crucial to achieving high performance PSCs. To have better interactions of the light absorbing layers with the electron transport layers or hole transport layers, the surfaces need to be uniform and appropriately oriented. ${ }^{[131-134]}$ ILs have been successfully used as crystallization solvents for methylammonium lead iodide $\left(\mathrm{MAPbI}_{3}\right)$ films via spin-coating or drag-coating. ${ }^{[135]}$ Since the initial report several ILs including methylammonium formate, ${ }^{[136]}$ tetraphenylphosphonium iodide and chloride, [137] 1-hexyl-3-methylimidazolizm chloride, ${ }^{[138,139]}$ and 1-ethylpyridinium chloride ${ }^{[140]}$ have been used to modify perovskite structures (Fig. 5).

Functionalized ILs containing a fluorous group, i.e. 1-methyl-3- $(1 \mathrm{H}, 1 \mathrm{H}, 2 \mathrm{H}, 2 \mathrm{H}-$ nonafluorohexyl)-imidazolium iodide and 1,1,1-trifluoro-ethyl-ammonium iodide, employed as dopants in the fabrication of perovskite films lead to devices with extended lifetimes, ${ }^{[141,142]}$ Contact angle measurements of the films indicate that the surface is more hydrophobic with the cations mainly located on the surface of the perovskite film, therefore repelling water, which is known to deactivate perovskite materials. Alloys comprising methylammonium and alkylammonium cations combined with $\mathrm{PbI}_{3}^{-}$anions can also provide PSCs with improved stabilities, ${ }^{[143,144]}$ and ILs have also been used to modify electron transport materials in PSCs. ${ }^{[145,146]}$ ILs dopants also facilitate the crystallization of perovskite films; a series of ILs containing alkene, alkyne or nitrile functional groups (Fig. 5) were shown to modulate the morphology of perovskite films by influencing the rate of the crystallization process and improving the quality of the grain boundaries. ${ }^{[147]}$

\section{Concluding Remarks}

Room-temperature ILs are attractive alternatives to conventional solvents due to a plethora of unique properties combined with the ability to design new ILs with specific properties for a wide and diverse range of applications. ILs are truly diverse and in this review we have selected a few examples from the vast body of literature which highlight the preparation of ILs and some of their applications, in particular, showing how they can be used in the fabrication of perovskite films. While a great deal more research is required to understand the role of ILs in fabrication of perovskite films, they have been shown to influence the crystallization process, improve the quality of the interfaces and provide other specific features dependent upon the properties of the IL used. Moreover, since ILs lower the over-potential in the electrocatalytic reduction of $\mathrm{CO}_{2},[148,149]$ and are key components in solar fuel devices, ${ }^{[150]}$ they may yet play further roles in the direct conversion of sunlight into fuels that harness perovskite materials.

Received: October 13, 2017 
Fig. 5. Examples of ILs used in the fabrication of perovskite films.
[35] Y.-X. An, M.-H. Zong, H. Wu, N. Li, Biores. Tech. 2015, 192, 165.

[36] T. V. Hoogerstraete, B. Onghena, K. Binnemans, J. Phys. Chem. Lett. 2013, 4, 1659.

[37] K. Sasaki, K. Takao, T. Suzuki, T. Mori, T. Arai, Y. Ikeda, Dalton Trans. 2014, 43, 5648.

[38] C. J. Bradaric, A. Downard, C. Kennedy, A. J. Robertson, Y. Zhou, Green Chem. 2002, 5, 143.

[39] I. Minami, T. Inada, R. Sasaki, H. Nanao, Tribol. Lett. 2010, 40, 225.

[40] B. Yu, D. G. Bansal, J. Qu, X. Sun, H Luo, S. Dai, P. J. Blau, B. G. Bunting, G. Mordukhovich, D. Smolenski, J. Wear 2012, 289, 58.

[41] A. E. Somers, P. C. Howlett, D. R. MacFarlane, M. Forsyth, Lubricants 2013, 1, 3 .

[42] T. L. Greaves, C. J. Drummond, Chem. Rev. 2007, 108, 206.

[43] K. Ghandi, Green Sust. Chem. 2014, 4, 44.

[44] A. Bhattacharjee, J. A. Coutinho, M. G. Freire, P. J. Carvalho, J. Solution Chem. 2015, 44, 703.

[45] A. Penttilä, P. Uusi-Kyyny, V. Alopaeus, Ind. Eng. Chem. Res. 2014, 53, 19322.

[46] A. Idris, R. Vijayaraghavan, A. F. Patti, D. R. MacFarlane, ACS Sustainable Chem. Eng. 2014, 2, 1888 .

[47] P. J. Dyson, P. G. Jessop, Catal. Sci. Technol. 2016, 6,3302

[48] M. J. Muldoon, C. M. Gordon, I. R. Dunkin, J. Chem. Soc., Perkin Trans. 2 2001, 433.

[49] L. Crowhurst, P. R. Mawdsley, J. M. PerezArlandis, P. A. Salter, T. Welton, Phys. Chem. Chem. Phys. 2003, 5, 2790.

[50] J.-M. Lee, S. Ruckes, J. M. Prausnitz, J. Phys. Chem. B 2008, 112, 1473.

[51] R. Lungwitz, S. Spange, New J. Chem. 2008 32,392 .

[52] P. G. Jessop, D. A. Jessop, D. Fu, L. Phan, Green Chem. 2012, 14, 1245.

[1] J. S. Wilkes, M. J. Zaworotko, J. Chem. Soc. Chem. Commun. 1992, 965.

[2] J. S. Wilkes, Green Chem. 2002, 4, 73.

[3] A. E. Visser, R. P. Swatloski, W. M. Reichert, R Mayton, S. Sheff, A. Wierzbicki, J. H. Davis, Jr., R. D. Rogers, Chem. Commun. 2001, 135.

[4] D. Zhao, Z. Fei, T. J. Geldbach, R. Scopelliti, P. J. Dyson, J. Am. Chem. Soc. 2004, 126, 15876.

[5] N. V. Plechkova, K. R. Seddon, Chem. Soc. Rev. 2008, 37, 123

[6] L. Chen, M. Sharifzadeh, N. M. Dowell, T. Welton, N. Shah, J. P. Hallett, Green Chem. 2014, 16, 3098 .

[7] X. Hu, S. Zhang, Y. Liu, C. Qu, L. Lu, X. Ma, X. Zhang, Y. Deng, Appl. Phys. Lett. 2011, 99, 213505.

[8] S. Dandavino, C. Ataman, C. N. Ryan, S. Chakraborty, D. Courtney, J. P. W. Stark, H. Shea, J. Micromech. Microeng. 2014, 24 075011 .

[9] M. J. Earle, J. M. S. S. Esperança, M. A. Gilea, J. N. Canongia Lopes, L. P. N. Rebelo, J. W. Magee, K. R. Seddon, J. A. Widegren, Nature 2006, 439, 831 .

[10] C. Ye, W. Liu, Y. Chen, L. Yu, Chem. Commun. 2001, 2244.

[11] Y. Cao, T. Mu, Ind. Eng. Chem. Res. 2014, 53, 8651.

[12] P. Bonhôte, A.-P. Dias, N. Papageorgiou, K. Kalyanasundaram, M. Grätzel, Inorg. Chem. 1996, 35, 1168 .

[13] Z. Fei, T. J. Geldbach, D. Zhao, P. J. Dyson, Chem. Eur. J. 2006, 12, 2122.

[14] Z. Fei, P. J. Dyson, Chem. Commun. 2013, 49 , 2594.

[15] 'Ionic Liquids in Synthesis', Eds P. Wasserschied, T. Welton, VCH-Wiley, Weinheim, 2002

[16] Y. Ishihara, A. Montero, P. S. Baran, 'The Portable Chemist's Consultant', v. 2.6.1; Apple Publishing Group, 2015.
[17] R. S. Varma, V. V. Namboodiri, Chem. Commun 2001, 643.

[18] V. V. Namboodiri, R. S. Varma, Org. Lett. 2002, 4, 3161 .

[19] M. Messali, Arabian J. Chem. 2014, 7, 63.

[20] S. V. Dzyuba, R. A. Bartsch, Chem. Commun. 2001, 1466.

[21] J. E. Bara, Ind. Eng. Chem. Res. 2011, 50, 13614.

[22] Z. Fei, D. Zhao, T. J. Geldbach, R. Scopelliti, P. J. Dyson, Chem. Eur. J. 2004, 10, 4886.

[23] V. Gallo, P. Mastrorilli, C. F. Nobile, G. Romanazzi, G. P. Suranna, J. Chem. Soc. Dalton Trans. 2002, 4339.

[24] P. J. Dyson, D. J. Ellis, W. Henderson, G Laurenczy, Adv. Synth. Catal. 2003, 345, 216.

[25] K. Takao, Y. Ikeda, Chem. Lett. 2008, 37, 682.

[26] Z.-B. Zhou, M. Takeda, M. Ue, J. Fluor. Chem. 2004, 125, 471.

[27] D. J. Kim, K. H. Oh, J. K. Park, Green Chem. 2014, 16, 4098.

[28] S. Petit, R. Azzouz, C. Fruit, L. Bischoff, F. Marsais, Tetrahedron Lett. 2008, 49, 3663.

[29] D. Esposito, S. Kirchhecker, M. Antonietti, Chem. Eur. J. 2013, 19, 15097.

[30] L. Chen, G. E. Mullen, M. Le Roch, C. G. Cassity, N. Gouault, H. Y. Fadamiro, R. E. Barletta, R. A. O'Brien, R. E. Sykora, A. C. Stenson, K. N. West, H. E. Horne, J. M. Hendrich, K. R. Xiang, J. H. Davis Jr., Angew. Chem. Int. Ed. 2014, 53, 11762.

[31] Y. Jeong, J.-S. Ryu, J. Org. Chem. 2010, 75, 4183.

[32] G. P. S. Lau, H. N. Tsao, S. M. Zakeeruddin M. Grätzel, P. J. Dyson, ACS Appl. Mater. Interfaces 2014, 6, 13571.

[33] M. Petkovic, K. R. Seddon, L. P. N. Rebelo, C. S. Pereira, Chem. Soc. Rev. 2011, 40, 1383.

[34] K. Ninomiya, A. Ohta, S. Omote, C. Ogino, K. Takahashi, N. Shimizu, Chem. Eng. J. 2013, $215-216,811$.
[53] H. Weingärtner, Angew. Chem. Int. Ed. 2008 , 47, 654.

[54] S. A. Katsyuba, T. P. Griaznova, A. Vidiš, P. J. Dyson, J. Phys. Chem. B 2009, 113, 5046. Rev. 2008, 37, 1709

[56] K. Bica, P. Gaertner, P. J. Gritsch, A. K. Ressmann, C. Schroeder, R. Zirbs, Chem. Commun. 2012, 48, 5013 .

[57] S. Tiwari, A. Kumar, Angew. Chem. Int. Ed. 2006, 45, 4824.

[58] J. A. Boon, J. A. Levisky, J. L. Pflug, J. S Wilkes, J. Org. Chem. 1986, 51, 480.

[59] M. Chen, Y. Luo, G. Li, M. He, J. Xie, H. Li, X. Yuan, Korean J. Chem. Eng. 2010, 26, 1563.

[60] C. Z. Qiao, Y. F. Zhang, J. C. Zhang, C. Y. Li, Appl. Catal. A 2004, 276, 61.

[61] D. J. M. Snelders, P. J. Dyson, Org. Lett. 2011, 13, 4048 .

[62] J. A. Berson, Z. Hamlet, W. A. Mueller, J. Am. Chem. Soc. 1962, 84, 297

[63] E. Janus, I. Goc-Maciejewska, M. Łożyński, J. Pernak, Tetrahedron Lett. 2006, 47, 4079.

[64] A. Vidis, C. A. Ohlin, G. Laurenczy, E. Küsters, G. Sedelmeier, P. J. Dyson, Adv. Synth. Catal. 2005, 347, 266

[65] A. Vidis, G. Laurenczy, E. Küsters, G. Sedelmeier, P. J. Dyson, J. Phys. Org. Chem. 2007, 20, 109 .

[66] A. Vidis, E. Küsters, G. Sedelmeier, P. J. Dyson, J. Phys. Org. Chem. 2008, 21, 264.

[67] Y. Chauvin, L. Mussmann, H. Olivier, Angew. Chem. Int. Ed. 1996, 34, 2698.

[68] P. Wasserscheid, H. Waffenschmidt, P. Machnitzki, K. W. Kottsieper, O. Stelzer, Chem. Commun. 2001, 451.

[69] T. J. Geldbach, P. J. Dyson, J. Am. Chem. Soc 2004, 126, 8114.

[70] T. J. Geldbach, D. Zhao, N. C. Castillo, G Laurenczy, B. Weyershausen, P. J. Dyson, $J$. Am. Chem. Soc. 2006, 128, 9773.
[55] T. L. Greaves, C. Drummond, J. Chem. Soc 
[71] P. Migowski, J. Dupont, Chem. Eur. J. 2007, $13,32$.

[72] J. Dupont, J. D. Scholten, Chem. Soc. Rev. 2010, 39, 1780

[73] K. Richter, P. S. Campbell, T. Baecker, A. Schimitzek, D. Yaprak, A.-V. Mudring, Phys. Status Solidi B 2013, 250, 1152.

[74] D. Zhao, Z. Fei, W.-H. Ang, P. J. Dyson, Small 2006, 2,879 .

[75] I. Biondi, V. Laporte, P. J. Dyson, ChemPlusChem 2012, 77, 7216.

[76] W. Miao, T. H. Chan, Acc. Chem. Res. 2006, 39, 897.

[77] X.-E. Wu, L. Ma, M.-X. Ding, L.-X. Gao, Synlett 2005, 607.

[78] X. Chen, D. Xu, L. Qiu, S. Li, W. Zhang, F Yan, J. Mater. Chem. A 2013, 1, 8759 .

[79] W. Qian, E. Jin, W. Bao, Y. Zhang, Angew. Chem. Int. Ed. 2005, 44, 952.

[80] S. T. Handy, M. Okello, J. Org. Chem. 2005, 70,2874

[81] X. He, T. H. Chan, Tetrahedron 2006, 62, 3389.

[82] M. K. Muthyala, S. Choudhary, A. Kumar, $J$. Org. Chem. 2012, 77, 8787.

[83] C. P. Mehnert, Chem. Eur. J. 2005, 11, 50.

[84] A. Riisager, R. Fehrmann, M. Haumann, P. Wasserscheid, Top. Catal. 2006, 40, 91.

[85] C. P. Mehnert, R. A. Cook, N. C. Dispenziere, M. Afeworki, J. Am. Chem. Soc. 2002, 124, 12932.

[86] M. Gruttadauria, S. Riela, P. Lo Meo, F. D’Anna, R. Noto, Tetrahedron Lett. 2004, 45 , 6113.

[87] B. S. Lee, Y. S. Chi, J. K. Lee, I. S. Choi, C E. Song, S. K. Namgoong, S.-g. Lee, J. Am. Chem. Soc. 2004, 126, 480.

[88] L. Rodríguez-Pérez, E. Teuma, A. Falqui, M Gómez, P. Serp, Chem. Commun. 2008, 4201.

[89] Y. S. Chi, J. K. Lee, S.-G. Lee, I. S. Choi, Langmuir 2004, 20, 3024.

[90] J. Liu, J. Li, B. Yu, B. Ma, Y. Zhu, X. Song, X. Cao, W. Yang, F. Zhou, Langmuir 2011, 27 , 11324

[91] Q. Ye, T. Gao, F. Wan, B. Yu, X. Pei, F. Zhou, Q. Xue, J. Mater. Chem. 2012, 22, 13123.

[92] J. Cuan, B. Yan, RSC Adv. 2014, 4, 1735.

[93] Z.-Y. Yan, B. Yan, New J. Chem. 2014, 38, 2604

[94] L. Chen, B. Yan, Spectrochim. Acta A 2015, 151,100

[95] Z. Fei, T. J. Geldbach, R. Scopelliti, P. J. Dyson, Inorg. Chem. 2006, 45, 6331.

[96] X.-C. Chai, Y.-Q. Sun, R. Lei, Y.-P. Chen, S. Zhang, Y.-N. Cao, H.-H. Zhang, Cryst. Growth Des. 2009, 10,658

[97] Z. Fei, T. J. Geldbach, D. Zhao, R. Scopelliti, P. J. Dyson, Inorg. Chem. 2005, 44, 5200 .

[98] Z. Fei, W. H. Ang, T. J. Geldbach, R. Scopelliti, P. J. Dyson, Chem. Eur. J. 2006, 12, 4014

[99] Z. Fei, D. Zhao, T. J. Geldbach, R. Scopelitti, P. J. Dyson, Angew. Chem. Int. Ed. 2005, 44, 5720.

[100] K. Jin, X. Huang, L. Pang, J. Li, A. Appel, S. Wherland, Chem. Commun. 2002, 2872.

[101] E. R. Cooper, C. D. Andrews, P. S. Wheathley, P. B. Webb, P. W. Wormald, R. E. Morris, Nature 2004, 430, 1012.

[102] R. E. Morris, Chem. Commun. 2009, 2990.
[103] K. Fujie, T. Yamada, R. Ikeda, H. Kitagawa, Angew. Chem. Int. Ed. 2014, 53, 11302.

[104] K. Fujie, K. Otsubo, R. Ikeda, T. Yamada, H. Kitagawa, Chem. Sci. 2015, 6, 4306.

[105] Y. Chen, Z. Hu, K. M. Gupta, J. Jiang, J. Phys. Chem. C 2011, 115, 21736.

[106] K. M. Gupta, Y. Chen, Z. Hu, J. Jiang, Phys. Chem. Chem. Phys. 2012, 14, 5785.

[107] K. B. Sezginel, S. Keskin, A. Uzun, Langmuir 2016, 32, 1139.

[108] Q. Luo, M. Ji, M. Lu, C. Hao, J. Qiu, Y. Li, J. Mater. Chem. A 2013, 1,6530 .

[109] F. D. Bobbink, P. J. Dyson, J. Catal. 2016, 343,52 .

[110] E. D. Bates, R. D. Mayton, I. Ntai, J. H. Davis, Jr., J. Am. Chem. Soc. 2002, 124, 926.

[111] J. Ma, Y. Ying, X. Guo, H. Huang, D. Liu, C. Zhong, J. Mater. Chem. A 2016, 4, 7281.

[112] M. J. Muldoon, P. Nockemann, M. C. Lagunas, CrystEngComm 2012, 14, 4873.

[113] E. Ahmed, J. Breternitz, M. F. Groh, M. Ruck, CrystEngComm 2012, 14, 4874.

[114] W. L. Hough, M. Smiglak, H. Rodriguez, R. P. Swatloski, S. K. Spear, D. T. Daly, J. Pernak, J. E. Grisel, R. D. Carliss, M. D. Soutullo, J. H. Davis, Jr., R. D. Rogers, New J. Chem. 2007, $31,1429$.

[115] C. C. Weber, S. A. Kulkarni, A. J. KunovKruse, R. D. Rogers, A. S. Myerson, Cryst. Growth Des. 2015, 15, 4946.

[116] V. Jaitely, A. Karatas, A. T. Florence, Int. J. Pharm. 2008, 354, 168.

[117] P. Wang, S. M. Zakeeruddin, P. Comte, I. Exnar, M. Grätzel, J. Am. Chem. Soc. 2003, $125,1166$.

[118] F. Mazille, Z. Fei, D. Kuang, D. Zhao, S. M. Zakeeruddin, M. Grätzel, P. J. Dyson, Inorg. Chem. 2006, 45, 1585

[119] Z. Fei, D. Kuang, D. Zhao, C. Klein, W. H. Ang, S. M. Zakeeruddin, M. Grätzel, P. J. Dyson, Inorg. Chem. 2006, 45, 10407.

[120] M. Marszalek, Z. Fei, D.-R. Zhu, R. Scopelliti, P. J. Dyson, S. M. Zakeeruddin, M. Grätzel. Inorg. Chem. 2011, 50, 11561

[121] G. P. S. Lau, J.-D. Decoppet, T. Moehl, S. M. Zakeeruddin, M. Graetzel, P. J. Dyson, Sci. Rep. 2015, 5, 18158

[122] G. P. S. Lau, H. N. Tsao, C. Yi, S. M Zakeeruddin, M. Graetzel, P. J. Dyson, ChemSusChem 2015, 8, 255 .

[123] E. Vijayakumar, A. Subramania, Z. Fei, P. J. Dyson, RSC Adv. 2015, 5, 52026.

[124] V. Elayappan, V. Murugadoss, S. Angaiah, Z. Fei, P. J. Dyson, J. Appl. Polym. Sci. 2015, $132,42777$.

[125] E. Vijayakumar, A. Subramania, Z. Fei, P. J. Dyson, J. Appl. Polym. Sci. 2015, 132, 42032.

[126] D. Wang, M. Wright, N. K. Elumalai, A Uddin, Sol. Energy Mater. Sol. Cells 2016, 147, 255.

[127] G. Niu, X. Guo, L. Wang, J. Mater. Chem. A 2015, 3, 8970 .

[128] A. Babayigit, A. Ethirajan, M. Muller, B. Conings, Nature Mater. 2016, 15, 247.

[129] www.nrel.gov

[130] W. E. I. Sha, X. Ren, L. Chen, W. C.H. Choy, Appl. Phys. Lett. 2015, 106, 221104.
[131] Y. Yang, M. Yang, D. T. Moore, Y. Yan, E. M. Miller, K. Zhu, M. C. Beard, Nat. Energy 2017, 2, 16207.

[132] M. Yang, Y. Zeng, Z. Li, D. H. Kim, C.-S. Jiang, J. van de Lagemaat, K. Zhu, Phys. Chem. Chem. Phys. 2017, 19, 5043

[133] B. Conings, S. A. Bretschneider, A. Babayigit, N. Gauquelin, I. Cardinaletti, J. Manca, J. Verbeeck, H. J. Snaith, H.-G. Boyen, ACS Appl. Mater. Interfaces 2017, 9, 8092.

[134] M. Lira-Cantú, Nat. Energy 2017, 2, 17115.

[135] D. T. Moore, K. W. Tan, H. Sai, K. P. Barteau, U. Wiesner, L. A. Estroff, Chem. Mater. 2015 27,3197

[136] N. Cho, F. Li, B. Turedi, L. Sinatra, S. P. Sarmah, M. R. Parida, M. I. Saidaminov, B. Murali, V. M. Burlakov, A. Goriely, O F. Mohammed, T. Wu, O. M. Bakr, Nat. Commun. 2016, 7, 13407.

[137] C. Sun, Q. Xue, Z. Hu, Z. Chen, F. Huang, H.L. Yip, Y. Cao, Small 2015, 11, 3344

[138] M. Shahiduzzaman, K. Yamamoto, Y Furumoto, T. Kuwabara, K. Takahashi, T. Taima, RSC Adv. 2015, 5, 77495 .

[139] M. Shahiduzzaman, K. Yamamoto, Y Furumoto, T. Kuwabara, K. Takahashi, T. Taima, Jpn. J. Appl. Phys. 2016, 55, 02BF05.

[140] Y. Wan, S. Dong, Y. Wang, L. Yang, W. Qin, H. Cao, C. Yao, Z. Ge, S. Yin, RSC Adv. 2016, 6 , 97848.

[141] M. Salado, F. J. Ramos, V. M. Manzanares, P. Gao, M. K. Nazeeruddin, P. J. Dyson, S. Ahmad, ChemSusChem 2016, 9, 2708.

[142] D. Bi, P. Gao, R. Scopelliti, E. Oveisi, J. Luo, M. Grätzel, A. Hagfeldt, M. K. Nazeeruddin, Adv. Mater. 2016, 28, 2910.

[143] W. Peng, X. Miao, V. Adinolfi, E. Alarousu, O. E. Tall, A.-H. Emwas, C. Zhao, G. Walters, J. Liu, O. Ouellette, J. Pan, B. Murali, E. H. Sargent, O. F. Mohammed, O. M. Bakr, Angew. Chem. Int. Ed. 2016, 55, 10686.

[144] Z. Wang, Q. Lin, F. P. Chmiel, N. Sakai, L. M. Herz, H. J. Snaith, Nat. Energy 2017, 2 , 17135.

[145] D. Yang, R. Yang, X. Ren, X. Zhu, Z. Yang, C. Li, S. F. Liu, Adv. Mater. 2016, 28, 5206.

[146] D. Yang, X. Zhou, R. Yang, Z. Yang, W. Yu, X: Wang, C. Li, S. F. Liu, R. P. H. Chang, Energy Environ. Sci. 2016, 9, 3071

[147] Y. Zhang, Z. Fei, P. Gao, Y. Lee, F. F. Tirani, R. Scopelliti, Y. Feng, P. J. Dyson, M. K. Nazeeruddin, Adv. Mater. 2017, 29, 1702157.

[148] B. A. Rosen, A. Salehi-Khojin, M. R. Thorson, W. Zhu, D. T. Whipple, P. J. A. Kenis, R. I. Masel, Science 2011, 334, 643.

[149] G. P. S. Lau, M. Schreier, D. Vasilyev, R Scopelliti, M. Grätzel, P. J. Dyson, J. Am Chem. Soc. 2016, 138, 7820.

[150] M. Asadi, K. Kim, C. Liu, A.V. Addepalli, P. Abbasi, P. Yasaei, P. Phillips, A. Behranginia, J. M. Cerrato, R. Haasch, P. Zapol, B. Kumar, R. F. Klie, J. Abiade, L. A. Curtiss, A. SalehiKhojin, Science 2016, 353, 467. 